\title{
Freedom of movement of workers as a condition for implementing the Europe 2020 strategy for employment and growth
}

\begin{abstract}
This article aims to analyse freedom of movement of workers in the context of the new strategies for EU growth and employment. Freedom of movement of people, especially workers, is one of the four freedoms of the EU internal market. Migrant workers who move to another member state enjoy certain rights stipulated by EU laws and are important in terms of fulfilling the employment gap and creating new jobs. Europe 2020 is the EU's growth strategy for the next period and embodies five ambitious objectives - employment; innovation; education; social inclusion; and climate/energy. Each member state has adopted its own national targets in each of these areas, while concrete actions at EU and national levels underpin the Strategy. These goals will not be fulfilled if freedom of movement is not realised, whereas the agenda for new skills and jobs has the objective of creating the right conditions to modernise labour markets. The author goes on to analyse the elimination of impediments to freedom of movement regarding the goals set in the new strategy.
\end{abstract}

Keywords: freedom of movement of workers, migrant workers, growth, employment, 2020 Strategy, financial crisis, sustainability, economic and social cohesion, poverty, inclusion, labour markets, employment structural change, qualifications

\section{Introduction}

The basic idea behind the creation of the European Union is the internal market, which envisages the free movement of people, capital, services and goods. The creation of the internal market is the central raison d'être of the EU's existence. The free movement of people is, therefore, one of the four freedoms of the internal market and the right to movement is a basic right for European citizens. However, the realisation of this freedom has been tougher than the practice of the free movement of capital, services and goods. Therefore, the EU is still taking subsequent actions to realise citizens' freedom of movement. In the beginning, people's freedom of movement was available just for the working population but, later on, freedom of movement has included all categories of citizens, students, retired people and people who are not economically active.

Over the years, the European Union has made efforts to change its approach towards third country nationals, especially as regards the working population, as one of the conditions for the fulfilment of the goals of the Lisbon Strategy. The European Union has adopted important primary and secondary law, while there is important case law from the European Court of Justice. Furthermore, Association Agreements seek to regulate the freedom of movement of third country workers via the provision of articles 
for the free movement of such workers in the European Union, and vice versa. For a long time, Association Agreements have provided the basis of laws regulating the freedom of movement of third country workers, while the European Court of Justice has played an important role in interpreting articles for the freedom of movement of workers and giving these direct effect in the national laws of member states.

In the last two years, the European Union has adopted secondary laws for improving the status of third country workers, especially for highly-qualified ones. The entry of highly-qualified workers into member states is important for the realisation of economic growth and development, such as the goal of decreasing the rate of unemployment.

Free movement of workers in the EU - what does it mean?

\section{Direct effect of Article 39 TEC}

The central legal questions concerning the free movement of workers are the direct effect of Article 39 (ex-Article 48) of the Treaty establishing the European Community: setting down the meaning of the term 'migrant worker', as well as certain rights of the migrant worker's family members. The Treaty on European Union establishes the concept of European citizenship, thereby giving certain rights and obligations to European citizens, as well as limited rights and obligations to non-EU citizens.

The Treaty of Amsterdam moved important issues regulating the status of non-EU citizens from the third to the first EU pillar, thus making it part of the acquis communautaire.

The European Court of Justice has played an important role in interpreting the meaning of Article 39 on the free movement of workers. The Court constantly points to the meaning of the free movement of workers and the realisation of the principle of non-discrimination based on nationality. Article 12 of the TEU explicitly forbids any form of discrimination based on nationality when putting into practice the Treaty's Articles. The Council of Ministers has jurisdiction in compliance with Article 251 to adopt acts forbidding discrimination based on nationality.

The definition of the term 'worker' has been of major interest to the European Community. In the Hoekstra case, ${ }^{1}$ the European Court of Justice interpreted that the definition of 'worker' is not a question of the national law of the member state, but that it is in the interest of all member states to interpret this term uniformly. Interpreting this term uniformly implies that it is crucial in terms of establishing the internal market.

The most important goal of the internal market could not be achieved if the term 'migrant worker' was to be defined by the national law of each member state. Two questions are particularly important in this judgment. Firstly, the Court gave the term 'migrant worker' a communitarian emphasis, meaning that the Court gave directions for its application in the member states. The second important meaning is that the Court interpreted this term extensively, because the realisation of free movement is one of the four freedoms and a conditio sine qua non for the realisation of the internal market.

1 Hoekstra v Bestuur der Bedrijfsverening voor detailhandel en Amachten, 6 ECR 177. 


\section{Rights of migrant workers}

Article 39 of the EC Treaty entails important rights for migrant workers when moving from one member state to another:

- the right to look for a job in another member state

- the right to work in another member state

- the right to reside there for that purpose

- the right to remain there

- the right to equal treatment in respect of access to employment, working conditions and all other advantages which could help facilitate the worker's integration in the host member state. ${ }^{2}$

\section{The problems with EU worker mobility over the years}

The freedom of movement of workers within the European Union has been implemented across the years but has had to face legal, administrative and practical problems in its realisation. Today, the European labour market offers more and better rules for the EU's migrant workers. The European Union has adopted new legislation for the protection of migrant workers and has increased the flexibility of the labour market. The mobility of workers within the EU was very low at the time when the EU legislation on freedom of movement of workers was adopted.

2006 was nominated the year of mobility for EU workers. The European Commission nominated this year in this way because of the low percentage of EU citizens who migrated for work to another member state from their country of origin: only $2 \%$ of EU workers used the right of mobility in compliance with EU legislation. Thus, it was necessary to apply additional measures. This percentage was maintained unchanged over the thirty years of implementing legislation on workers' freedom of movement. One survey reported that only $30 \%$ of EU citizens said that, in some period of their life, they intended to change their place of origin vis-à-vis the other $70 \%$ that had no intention of moving to another member state. ${ }^{3}$ Women, older people and low-skilled workers are the main categories of people who wanted to change their current place of residence and search for work in other member state although, as we can see, most European citizens do not intend to change their country of origin. In most cases, the situation is due to current satisfaction with the work that people are carrying out. However, more than $40 \%$ of workers expect to change their current job, because of their professional careers or simply because they want to make changes to their life. ${ }^{4}$

Mobility in the EU is basically understood as a way of improving flexibility, managing labour inequalities and improving economic growth. ${ }^{5}$ The European Union has aimed to improve mobility at the level of the EU across the years. Thus, the European Commission has adopted special measures like its Action Plan for Skills and Mobili-

2 http://eur-lex.europa.eu/en/treaties/index.htm.

3 MEMO 06/83, Brussels, 20 February 2006.

4 http://europa.eu.int/comm/employment_social/workersmobility2006/events_en.htm.

5 Master's thesis: Alexandra Lewarth, 2002/03, p. 34. 
ty, ${ }^{6}$ creating such things as the European information web pages for work mobility. ${ }^{7}$ The European Commission has confirmed that worker mobility is expected in the future, especially for highly-qualified workers as a result of policies, technical improvements and rapid economic integration.

The European page for work mobility is a concrete instrument in terms of establishing improvements in mobility. The page gives a clear picture of workers who are searching for a job as a result of the public advertisement of job vacancies standing at one million at any given moment. The page is visited by 500000 people every month, providing an opportunity for a short biography and information on working and living standards in other member states.

The European Commission has also promoted the EURES Network, in order to facilitate freedom of movement of workers in the European Economic Area and Switzerland. This system has replaced the European system for the international publication of job vacancies and applications for work. The partners in EURES are public employment services, trade unions and other workers' associations. The most important tasks for EURES are:

- to disseminate information and advice on the potential mobility of workers in the European Economic Area

- to assist in the employment of foreign workers

- to give advice and rules for workers and employees in cross-border areas. ${ }^{8}$

\section{The EU 2020 Strategy for Employment and Growth}

Europe 2020 is the growth strategy for the decade between 2010 and 2020, and focuses on the three mutually reinforcing priorities of smart, sustainable and inclusive growth. This programme aims to deliver high levels of employment, productivity and social cohesion and to deal with the adverse effects of the financial economic crisis. The Europe 2020 Strategy has set five ambitious objectives, all to be attained by 2020 , on employment; innovation; education; climate/energy; and social inclusion. Each member state has adopted its own national targets in each area and has also set its own measures at national level to underpin the Strategy. The engines driving this growth are knowledge and innovation; greener and more efficient use of resources; higher employment; and better social and territorial cohesion. ${ }^{9}$

In this direction, the European Union had also implemented its Lisbon Strategy. The goal of the Lisbon Strategy was to make the European Union 'the most dynamic and competitive knowledge-based economy in the world' by 2010. At the time, it was already recognised that the reform agenda needed to achieve this very ambitious objective could not be pursued at EU level alone, but that reforms at the level of member states were also necessary as, in many of the policy fields involved, competence remained at national level.

6 COM 2002/0072 final.

7 https://ec.europa.eu/eures/.

8 http://ec.europa.eu/eures/main.jsp?catId=27\&acro=eures\&lang=en.

9 Commission of the European Communities (2009) Consultation on the future EU 2020 strategy Commission working document, Brussels, COM(2009)647/3. 
For many commentators, however, the overall direction of the Strategy was still flawed, but the realisation of this came too late to allow it to shift its course. The 2007 financial and economic crisis was the final blow to the Strategy, cutting EU growth and boosting unemployment numbers to historically low figures. ${ }^{10}$

The financial crisis influenced different countries differently. It was strongest in countries like Spain and Ireland vis-à-vis more sustainable EU member states economies, such as Germany and France. Germany and France increased their employment rates among their populations aged $20-64$ from $66 \%$ to $70 \%$. Germany managed to increase its employment rate from $67 \%$ in 2004 to $75 \%$ in 2010.

According to Eurostat data, $2.3 \%$ of EU citizens (11.3 million people) were residing in a member state other than the state of their origin in 2008. According to a recent Eurobarometer survey, $10 \%$ of citizens included in the survey, from different member states, replied that they had lived and worked in another country at some point in the past, while $17 \%$ intended to move freely in the future. ${ }^{11}$

Regarding problems with movement and the impact of financial crisis, the European Commission proposed, and the European Council adopted at its 2010 Spring Summit, the Europe 2020 Strategy. The main objective of the Europe 2020 Strategy is to bring together the economic, social and environmental agendas of the EU in a more structured and coherent way. The idea is to mainstream some fundamental political objectives both at EU level (through the use of funding programmes and policy initiatives), as in the context of EU-driven national reforms. The 2020 Strategy aims to enhance policy synergies and, at the same time, reinforce the European integration process by offering a stronger vision and governance model.

The Strategy lays out five targets to be achieved by the European Union by 2020:

- $75 \%$ employment rate for the $20-64$ age group

- $3 \%$ investment rate in research and development

- 20/20/20 climate and energy targets (the reduction of greenhouse gas emissions by at least $20 \%$, a share of final energy consumption coming from renewable energy sources increased to $20 \%$, and a $20 \%$ improvement in energy efficiency)

- an improvement in education levels (a reduction of school drop-out rates and an increased share of the population having completed tertiary or equivalent education)

- a promotion of social inclusion, including a reduction in poverty.

The first three targets were already the drivers of the Lisbon Strategy, and were therefore adopted without major debate by the member states, but the education and social objectives were new and were not immediately attributed with measurable targets. In addition to measurable targets, the 2020 Strategy also introduced a series of

10 Pirgmaier, Elke (2008) Lisbon and Sustainable Development Strategies in the EU: How does mutual recognition take place in practice? Research Institute for Managing Sustainability (RIMAS), University of Economics and Business Administration: Vienna, Austria. Supervision: Reinhard Steurer, $\mathrm{PhD}$.

11 European Commission (2012) Reaping the benefits of globalization European Competitiveness Report 2012, COM(2012)582 final. 
actions and policies grouped under three main headings: smart growth; green growth; and inclusive growth.

In its 2020 paper, the Commission was still vague in describing the tools and programme under which the agenda would be realised. ${ }^{12}$

In respect of freedom of movement of workers, three initiatives are more important to be realised. Under the initiative Youth on the Move, the European Union, through the Europe 2020 Strategy, aims to enhance the performance and international attractiveness of Europe's higher education institutions and to raise the overall quality of education and training. Under the topic An Agenda for New Skills and Jobs, the EU aims to modernise labour markets, ensure the sustainability of European social models and empower people through the acquisition of new skills so as to adapt to new conditions and potential career shifts, reduce unemployment and raise labour productivity. Under the agenda of the European Platform Against Poverty, the EU aims to ensure social and territorial cohesion, such that the benefits of growth and jobs are widely shared and that people experiencing poverty and social exclusion are enabled to live in dignity and take an active part in society. ${ }^{13}$

How will freedom of movement of workers influence the goals of the Europe 2020 Strategy for Employment and Growth?

Freedom of movement of workers is important for fulfilling the needs of the workforce in EU member states. The realisation of this principle means a lowering of the unemployment rate at EU level during the time of crises. However, in order to respond effectively to the challenges and opportunities of globalisation, European policy-makers recognise that the EU has to become a more innovative and competitive economic player.

One important tool for achieving this goal is migration from one member state to other in EU border territories, such as immigration from third countries. A carefullyplanned immigration could lead to younger, more dynamic European societies, enhancing the exchange of people and ideas. This could stimulate risk-taking, foster the modernisation of European economies and societies, help to overcome rigid structures and lead to higher economic growth. Today, the size of the labour force in western and central Europe is 227 million. In the absence of immigration, and at constant labour force participation rates, the labour force would fall to 201 million in 2025 and to 160 million in 2050. In order to maintain it at a constant over the analysed period, a net inflow of 66 million labour migrants would be necessary. In 2005, twenty of the then 27 European Union countries had a positive migration balance; the only exceptions being the Baltic States, Bulgaria, the Netherlands, Poland and Romania. Net migration gains were highest in Cyprus ( $+27.2 \%$ of the total population); Spain $(+15.0 \%)$; and Ireland (+11.4\%). In countries like the Czech Republic, Italy and Slovenia, net migration turned an excess of deaths over births into a positive total population change. ${ }^{14}$

12 http://www.cultureactioneurope.org/lang-en/component/content/article/41-general/597-theeu-2020-strategy-analysis-and-perspectives.

13 http://www.bka.gv.at/site/7762/default.aspx.

14 http://www.oecd.org/dev/38295272.pdf. 
Empirical evidence from several EU countries shows that, in most cases, immigrants are complementary to domestic labour in the labour market and, thus, have no negative effects on the job prospects and wages of the resident labour force. One exception, however, is the construction sector. In many EU member states, the native workforce employed in this sector is highly unionised. Construction workers are, for example, protected against wage competition from immigrants through collective wage agreements and dismissal protection, instruments that have the unintended consequence of attracting more immigrants that would have been the case in their absence. Job mobility is a complex phenomenon and many factors influence it, including the characteristics of the job and the nature of the match between power relations and the job. Any model that is constructed to explain job mobility should include information on at least these three aspects. ${ }^{15}$

Free movement of workers, one of the four freedoms enshrined in the Treaty, contributes to economic development and social cohesion in the Union. However, there are a number of barriers to geographical mobility, ranging from legal and administrative obstacles, housing costs, portability of pensions and linguistic barriers to a lack of transparency in the area of job vacancies and in the provision of support for matching job-seekers with job offers. EURES aims to improve labour market transparency by making job vacancies available on the EURES Job Mobility Portal and to provide support for information, advice and guidance services at national and cross-border level.

At the same time, the role of public employment services has changed as a result of the recent economic crisis and the need for more tailor-made services. Public employment services should become lifelong learning providers, offering a wide range of services (such as skills assessment, training, career guidance, matching of jobs and profiles, and client counselling) and catering for the needs of those furthest from the labour market. In addition, EURES should promote new working methods with private employment services. ${ }^{16}$

Today, in the wake of the financial crisis, labour mobility has started to increase, mainly due to Europeans becoming more willing to relocate. A report for Deutsche Bank claims that internal migration can be an effective way of reducing disequilibria on labour markets, but some European countries have been alert to the risks of an increase in unemployment on the periphery of Europe. ${ }^{17}$

Even so, freedom of movement of workers is an important tool in attaining the goals of the Europe 2020 Strategy for Employment and Growth. In this direction, the work of EURES is important in correlation with those of the employment services.

In addition, one very important question is the equivalence of professional qualifications. Mutual recognition under Community law is automatic in respect of the oc-

15 Osberg, Lars (1993) Unemployment Insurance and Unemployment - Revisited Economics Department, Dalhousie University: Halifax, Nova Scotia. Revised version of a paper presented to Conference on 'Unemployment: What is to be Done?' Sudbury, Ontario, March 26/27, 1993.

16 COM/2011/0609 final - 2011/0270 (COD).

17 http://www.nouvelle-europe.eu/en/labour-mobility-europe-times-crisis. 
cupational activities of crafts workers, traders and farmers who have completed the relevant period of occupational experience in their domestic member state. Recognition is also automatic for lawyers practising under their 'home state professional title' on the basis of an authorisation to practise in their home member state. However, for other professions (engineers, physiotherapists and other professions supplementary to medicine, teachers, accountants, financial advisers, designers, urban planners, lawyers practising under a 'host title' and others covered by 'the General System for the recognition of professional qualifications' directives, which do not provide for any co-ordination of training), recognition is not guaranteed to be automatic.

\section{References}

Boswell, Christina, Silvia Stiller and Thomas Straubhaar (1994) Forecasting Labour and Skills Shortages: How Can Projections Better Inform Labour Migration Policies? Paper prepared for the European Commission, DG Employment and Social Affairs, Brussels: European Commission; Hamburg: HWWA.

Commission of the European Communities, Commission working document Consultation on the future EU 2020 strategy Brussels COM(2009)647/3.

Craig, P and Gráinne de Búrca (2003) EU Law, Text, Cases and Materials Oxford University Press: Oxford.

Eurobarometer (2005) Survey on geographic and labour market mobility http://europ a.eu.int/comm/employment_social/workersmobility2006/events_en.htm Com 2002/0072 final.

European Commission (2012) Reaping the benefits of globalization European Competitiveness Report 2012, COM(2012)582 final.

Gros, Daniel and Felix Roth (2012) Can the EU maintain the EU competitiveness in the world? Centre for European Policy Studies, CEPS: Brussels.

Hartley, T. C (2003) The Foundations of European Community Law Oxford University Press, pp. 212-223.

Lewarth, Alexandra (2003) Theory and Practice of European Labour Mobility in the Social Sector MACESS Dissertation 2002/03, Master in Comparative European Social Studies.

Osberg, Lars (1993) Unemployment Insurance and Unemployment - Revisited Economics Department, Dalhousie University: Halifax, Nova Scotia. Revised version of a paper presented to Conference on 'Unemployment: What is to be Done?' Sudbury, Ontario, March 26/27, 1993.

Pirgmaier, Elke (2008) Lisbon and Sustainable Development Strategies in the EU: How does mutual recognition take place in practice? Research Institute for Managing Sustainability (RIMAS), University of Economics and Business Administration: Vienna, Austria. Supervision: Reinhard Steurer, PhD. 
Proposal for a Regulation of the European Parliament and of the Council on a European Union Programme for Social Change and Innovation, COM/2011/0609 final 2011/0270 (COD).

https://ec.europa.eu/eures/

http://eur-lex.europa.eu/en/treaties/index.htm

http://ec.europa.eu/eures/main.jsp?catId=27\&acro=eures\&lang=en

http://www.cultureactioneurope.org/lang-en/component/content/article/41-general/

597-the-eu-2020-strategy-analysis-and-perspectives

http://www.bka.gv.at/site/7762/default.aspx

http://www.oecd.org/dev/38295272.pdf

http://www.nouvelle-europe.eu/en/labour-mobility-europe-times-crisis 